\title{
ПРОФЕСІЙНА ПІДГОТОВКА МАЙБУТНІХ УЧИТЕЛІВ ПОЧАТКОВОЇ ОСВІТИ В УНІВЕРСИТЕТАХ ЧЕСЬКОЇ РЕСПУБЛІКИ
}

5. Bardus, I. O. (2017). Fundamentalizatsiia zmistu profesiinoi pidhotovky maibutnikh fakhivtsiv u haluzi informatsiinykh tekhnolohii do produktyvnoi diialnosti [Fundamentalization of the content of professional training of future specialists in the field of information technologies to productive activity]. Scientific Notes of Ternopil National Pedagogical University named after Volodymyr Hnatyuk. Series: pedagogy. Ternopil, vol. 3, pp. 74-81. [in Ukrainian].

6. Bardus, I. O. (2016). Filosofski zasady kontseptsii fundamentalizatsii profesiinoi pidhotovky maibutnikh fakhivtsiv u haluzi informatsiinykh tekhnolohii
[Philosophical Foundations of concept of fundamentalization training of future specialists in information technology]. Problems of engineering and pedagogical education. Kharkiv: Ukrainska inzhenerno-pedahohichna akademiia (UIPA), vol. 52-53, pp. 7-17. [in Ukrainian].

7. Bublyk, V. V. (2015). Obiektno-oriientovane prohramuvannia [Object-oriented programming]. Kyiv: IT-knyha, 624 p. [in Ukrainian]

8. Hrytsiuk, Yu. I. \& Rak, T. Ye. (2011). Obiektnooriientovane prohramuvannia movoiu $S++$ [ObjectOriented Programming in C ++]. Lviv: LDU BZhD Publ, 404 p. [in Ukrainian].

Стаття надійшла до редакції 19.03.2018

УДК [371.134+373.3]+378.4(437.1/2)

DOI:

Катерина Біницька, кандидат педагогічних наук, доцент кафедри педагогіки Хмельницької гуманітарно-педагогічної академії

\section{ПРОФЕСІЙНА ПІДГОТОВКА МАЙБУТНІХ УЧИТЕЛІВ ПОЧАТКОВОЇ ОСВІТИ В УНІВЕРСИТЕТАХ ЧЕСЬКОЇ РЕСПУБЛІКИ}

У статті розглянуто окремі аспекти професійної підготовки майбутніх учителів початкової освіти в університетах Чеської Республіки. Визначено, що у 90-х роках ХХ ст. розпочалась реформа освіти. Зазначено, щчо Болонський процес став головним імпульсом до початку освітніх перетворень для закладів вищої освіти в країні. Проаналізовано нормативно-правову базу Чеської Республіки та акиентовано, щзо законодавчо закріплена вимога до вчителя початкової освіти мати ступінь вищої освіти "магістр".

Зазначено, щуо університети використовують комбіновану магістерську програму з тривалістю навчання 5 років.

Ключові слова: професійна підготовка; учителі початкової освіти; навчальний план; університети; Чеська Республіка.

Лim. 14.

Kateryna Binytska, Ph.D.(Pedagogy), Associate Professor of the Pedagogy Department Khmelnitskiy Humanitarian Pedagogical Academy

\section{PROFESSIONAL PREPARATION OFTHE FUTURE TEACHERS OF PRIMARY EDUCATION AT THE UNIVERSITIES OFTHE CZECH REPUBLIC}

The article examines some aspects of the professional training of the future primary school teachers in the universities of the Czech Republic. It is determined that in the 1990-s the reform of education began, which included modernization of the professional training of the future primary school teachers. It is generalized that from the point of view of professional pedagogical preparation, the reorganization was aimed at eliminating the unified approach to teachers training. It is found out that in the late 1990-s in the Czech Republic, the processes of modernizing of professional training of the future primary school teachers were implemented at 9 pedagogical faculties of universities.

It is mentioned that at the beginning of the XXI century the Bologna process became the major impetus to the beginning of educational transformations for the institutions of higher education in the Czech Republic. In Czechia, due to the requirement of the Berlin Communique on the introduction of the two-staged system of higher education at the pedagogical faculties of universities began to be carried out already since 2003/2004 academic year.

The legal framework of the Czech Republic has been analyzed in the article. It is emphasized that the Law "On Pedagogical Workers" establishes the requirement to the teacher of primary education to have a master's degree of higher education.

The analysis showed that, in addition to the partial reorganization in the education system, the complete modification of the curricula for the training of future primary school teachers has been conducted. It is found out that the curriculum consists of five components: general educational, subject (academic), subject didactic, pedagogical-psychological and specialization.

It is noted that the process of professional training of the future teacher of primary education is clearly structured. The total proportion of compulsory disciplines, disciplines by choice of the student and optional 


\section{ПРОФЕСІЙНА ПІДГОТОВКА МАЙБУТНІХ УЧИТЕЛІВ ПОЧАТКОВОЇ ОСВІТИ В УНІВЕРСИТЕТАХ ЧЕСЬКОЇ РЕСПУБЛІКИ}

subjects is as following: 50:40:10. The attention is drawn to the fact that universities use the combined master's program with the duration of 5 years of training, according to which 300 credits are allocated for the study of all disciplines in accordance with the curriculum.

Keywords: professional training; primary school teachers; curriculum; universities; the Czech Republic.

П остановка проблеми. У сучасному світі збільшуються вимоги до професійної підготовки педагога. Перш за все, якість професійної підготовки майбутніх вчителів розглядають у зв'язку з соціально-культурними змінами в суспільстві, особливо акцентуючи увагу на мінливі парадигми сучасної системи освіти. Рівень здобутої освіти громадянами у сучасному світі називають “прихованим багатством”, що є джерелом процвітання країни та запорукою сталого розвитку людських ресурсів. Вимоги до якості освіти постійно зростають в умовах змін у сучасному інформаційному суспільстві. Професійна підготовка майбутніх вчителів розглядається як ключовий інструмент реформування освіти та запровадження інновацій у освітній сфері. На сьогодні йде активний пошук нової ідентичності вчительської професії, щоб визначити значення і характер педагогічного професіоналізму. Ми погоджуємось 3 твердженням Л. Подлахової, що: “На сьогодні сучасна школа потребує гнучкого вчителя, який здатний відобразити зміни в суспільстві, культурі, науці, економіці і політиці" [5, 17].

Аналіз останніх досліджень і публікацій. Проблемі професійної підготовки майбутніх вчителів у Чеській Республіці присвячені праці Й. Васютової, Р. Вілдової, Р.Дитртової, Л. Подхалова, В. Спілкової, М. Хутова та ін. (R.Dytrtové i M. Krhutová, L. Podlahova, V. Spilkova, J. Vašutova, R. Wildova).

Мета статті - висвітлити окремі аспекти професійної підготовки майбутніх учителів початкової освіти в університетах Чеської Республіки.

Виклад основного матеріалу дослідження. Суспільний розвиток протягом минулого століття підтвердив, що пріоритетними галузями економіки $€$ ті, які ведуть до розвитку освіченості і креативності своїх громадян. Протягом XX ст. до професії вчителя в Чеській Республіці не було на рівні держави вимог щодо наявності обов'язкової вищої освіти у педагогів.

У 90-х роках XX ст. розпочалась реформа освіти, що включала не тільки перетворення шкільної освіти, підручників та інших дидактичних матеріалів, а також фахову підготовку вчителів. 3 точки зору професійної педагогічної підготовки, реорганізація була спрямована на усунення єдиного підходу до підготовки вчителів, який був однаковим щодо підготовки вчителів для різних шкільних рівнів, на різних факультетах університетів в усій Чехії. Колишня модель підготовки вчителів характеризувалася високим співвідношенням академічно-теоретично орієнтованих дисциплін, в яких соціалістична ідеологія відігравала значну роль. Навчання методології та практики навчання було одноманітним, формальним і для майбутньої педагогічної практики дуже незадовільним. Лекції та інші фронтальні методи навчання переважали в процесі підготовки майбутніх вчителів. Саме ці недоліки тогочасної системи професійної підготовки учителів сформували нову концепцію педагогічної освіти побудованої за принципами гуманізації, демократії, а також індивідуалізації та диференціації навчання [1, 441].

Ситуація з професійною підготовкою майбугніх вчителів початкових класів була помітно відмінною. Ще на початку 90-х рр. XX ст. на педагогічних факультетах університетів досягли домовленості про те, які підходити до підготовки вчителів початкової школи використовувати. Було визначено, що професійна педагогічна підготовка майбутніх вчителів початкової школи повинна здійснюватись лише на педагогічних факультетах, що мало позитивний ефект. Одним із "керівних принципів”, який використовували в процесі розробки нових навчальних планів був моніторинг та глибокий аналіз європейських тенденцій у підготовці вчителів для цього рівня освіти [2].

Проведений нами аналіз науково-педагогічної літератури показав, що наприкінці 1990 рр. в Чеській Республіці процеси модернізації професійної підготовки майбутніх вчителів початкової освіти були здійснені на 9 факультетах університетів. Інтенсивна співпраця педагогічних факультетів університетів привела до загальнонаціонального узгодження основної Концепції навчальної програми для педагогічних спеціальностей, основою якої було, окрім професіоналізації, застосування конструктивістських та рефлексивних концепцій у підготовці майбутніх учителів [11, 193].

Національна програма розвитку системи освіти в Чеській Республіці (Біла книга) [3], яка була оприлюднена в 2001 р. стала фундаментальним документом, у якому визначені нові вимоги до професійної підготовки майбугніх вчителів. На основі “Білої книги” у 2004 р. було прийнято Закон № 563/2004 "Про педагогічних 


\section{ПРОФЕСІЙНА ПІДГОТОВКА МАЙБУТНІХ УЧИТЕЛІВ ПОЧАТКОВОЇ ОСВІТИ В УНІВЕРСИТЕТАХ ЧЕСЬКОЇ РЕСПУБЛІКИ}

працівників, який визначає кваліфікаційні вимоги щодо виконання професійних обов'язків вчителя та інших педагогічних працівників” [14]. Відповідно до цього закону визначено рівні професійної підготовки майбутніх учителів, зокрема ступінь бакалавра та магістра, які визначені у Болонській системі [14]. Також до нормативно-правових актів, які регулюють професійну підготовки майбутніх учителів відноситься Концепція програм 3 підготовки вчителів, яка впливає не лише на вимоги щодо їх професійних кваліфікацій, але й на так звану програму реформ шкільної освіти, яку було введено в дію [13].

Законом "Про педагогічних працівників" визначено 16 педагогічних категорій, 3 яких категорія “вчитель” включає 10 основних посад; однак учитель середньої школи визначається ще в чотирьох під категоріях. Крім того, зазначено в кожній педагогічній категорії визначається вчитель для учнів з особливими освітніми потребами. Структура основних категорій вчителя копіює структуру системи освіти. Також у Законі визначено вимоги до професії вчителя, зокрема конкретизовано професійні кваліфікації, що фактично є вимогами до професійної підготовки за визначеною педагогічною спеціальністю. Під професійною кваліфікацією в законі розуміється, процес здобуття відповідного рівня освіти, тобто здобуття ступеня бакалавра чи магістра, та складання випускного іспиту, що називається абсолютним або екзаменом 3 вивчення школи. Зокрема, у 7 Закону № 563/2004 визначено, що вчитель початкової освіти повинен здобути ступінь магістр за акредитованими програмами підготовки в галузі педагогічної освіти [14].

На початку XXI ст. Болонський процес став головним імпульсом до початку освітніх перетворень для чеських закладів вищої освіти. Чехія спільно з іншими країнами поставила перед собою мету створити загальноєвропейський простір вищої освіти. Так, на вимогу Берлінського комюніке (2003 р.), щодо впровадження двоступеневої системи вищої освіти на педагогічних факультетах чеських університетів почали виконувати уже з 2003/2004 навчального року.

Сьогодні професійну педагогічну кваліфікацію можна отримати здобувши вищу освіту за акредитованої навчальної програми за конкретною спеціальністю, тобто підготовка вчителя початкової школи. Підготовка вчителя початкової школи відбувається за інтегрованою моделлю, результат якої є здобуття ступеня магістр. Навчальна програма підготовки вчителів початкової школи $\epsilon$ неструктурованою, однофазовою, паралельною. Мінімальний обсяг навчальних годин було затверджено Міністерством освіти та служить закладам вищої освіти як кількісний критерій орієнтації освітніх програм з підготовки вчителів.

Розглянемо компоненти навчальної програми підготовки вчителя початкової школи (1 рівень базової школи). Програма навчання складається 3 п'яти компонентів: загальноосвітнього, предметного (академічного), предметного дидактичного, педагогіко-психологічного та спеціалізації. Практична підготовка $є$ невід’ємною частиною предметної дидактики, педагогікопсихологічного змісту та спеціалізації 3 компонентами програми $[11,201]$. Представлені компоненти включені в профіль випускника. Загальноосвітній компонент (1 - 2 курс навчання) має індивідуально-культурологічний вимір. Він надає студентам знання та навички, переважно в галузях гуманітарних та соціальних наук, але частково навіть у галузях природничих наук та інформаційних технологій. Основні дисципліни цього компоненту включають філософію, історію, соціологію, етику, інтерактивні технології та іноземну мову. Предметний компонент $(1-3$ курс навчання) включає в себе професійну основу окремих предметів, що викладаються на першому рівні базової школи (чеська мова та література, математика, батьківство, загальна наука, музика, мистецтво, іноземна мова). Педагогікопсихологічний компонент включає систему теоретичних та прикладних дисциплін, що належать до педагогічних наук та психології. Його профілювання $є$ загальною дидактикою, орієнтованою на початкову освіту (на деяких факультетах загальна дидактика, включаючи теорію освіти, називається первинною педагогікою), історія та філософія освіти, суспільно-політичні науки, методологія дослідження в педагогіці, порівняльна педагогіка, альтернативна педагогіка, спеціальна педагогіка, психологія розвитку, освітня та соціальна психологія. Ці дисципліни вивчаються протягом п’яти років навчання і більшість з них інтегровані 3 практичною підготовкою. Компонент дидактики включає в себе курси, які сприяють розвитку дидактичних навичок, спрямованих на перетворення навчального матеріалу 3 урахуванням індивідуальної та вікової специфіки учнів молодшого шкільного віку. За цим модулем проводять підготовку студентів до теорії та практики навчання окремих предметів у початковій школі. Він вивчається протягом останніх двох-трьох років навчання. Компонент 


\section{ПРОФЕСІЙНА ПІДГОТОВКА МАЙБУТНІХ УЧИТЕЛІВ ПОЧАТКОВОЇ ОСВІТИ}

В УНІВЕРСИТЕТАХ ЧЕСЬКОЇ РЕСПУБЛІКИ

спеціалізації включає в себе курси, які дозволяють проводити індивідуальні профілі навчання. Компонент являє собою повну систему курсів в рамках обраної спеціалізації (існуючі спеціалізації - музика, мистецтво, театральне мистецтво, спеціальна педагогіка, навчання іноземної мови в початковій школі). У випадку, якщо спеціалізація іноземна мова, то курс вивчається протягом усієї програми підготовки; в інших випадках предмет спеціалізації вивчається протягом останніх трьох років навчання [11, 202].

Розглянемо заклади вищої освіти, у яких здійснюють професійну підготовку майбутніх вчителів початкової освіти в Чеській Республіці. Педагогічні факультети університетів пропонують спеціальності 3 підготовки вчителя 1 ступеня початкової школи за рівнем вищої освіти магістр. Крім того, ці факультети працюють 3 програмами навчання протягом усього життя. Аналіз діяльності чеських університетів показав, що в Чеській Республіці функціонують дев'ять факультетів, які акредитовані для надання докторських програм навчання або мають дозволи приймати державну докторську експертизу (rigorosum) [11, 204].

Зазначимо, що у Чехії заклади вищої освіти $\epsilon$ автономними, але повинні забезпечувати, щоб професійна педагогічна підготовка майбутніх вчителів становила принаймні 18 - 23\% загального обсягу навчальних годин $[4,34]$.

Розглянемо навчальний план зі спеціальності вчитель 1 ступеню початкової школи (Učitelství pro 1. stupeň Z $\breve{S}$ ), який використовують на педагогічному факультеті Університету Градец Кралове. В закладі пропонуються акредитовані програми вищої освіти рівень “магістр” у денній та у комбінованій формі навчання [6]. В університеті використовують комбіновану магістерську програму (Kombinovaná Magisterský) підготовки відповідно якої на вивчення всіх дисциплін згідно 3 навчальним планом відводиться 300 кредитів. Навчання здійснюється на чеській мові з тривалістю навчання 5 років [6].

До навчального плану входять: обов'язкові курси (262 кредитів); обов'язкові виборні курси; обов'язкові факультативні курси; необов'язкові предмети [6].

Зазначимо, що процес професійної підготовки майбутнього вчителя початкової освіти чітко структурований. Загальна пропорція обов'язкових, на вибір та факультативних предметів має такий вигляд: 50:40:10. Інновації в процесі професійної підготовки майбутнього вчителя полягають в тому, що характеризується введенням курсів, які відображають сучасну педагогічну теорію та практику, зокрема: полікультурна освіта, соціологія в освіті, інклюзивна педагогіка тощо. Трансформація змісту професійної підготовки майбутнього вчителя початкової освіти пов'язана 3 трансформацією форм навчання. Лекційна форма навчання в даний час замінена активними формами навчання - майстер класи, інтерактивні лекції тощо. Дуже часто використовують методи критичного мислення, аналіз роботи в класі за допомогою відеозаписів, методи моделювання та функції драматичного навчання $[10,5]$.

Аналіз процесу професійної підготовки майбутніх вчителів у Карлівському університеті м. Прага показав, що мета роботи магістерських студій зі спеціальності вчитель 1 ступеню початкової школи (Učitelství pro 1. stupeň ZŠ) полягає в тому, щоб надати випускникам професійні компетенції, які дозволять їм грамотно і ефективно здійснювати педагогічну діяльність в початковій школі. Навчання структуроване у шість модульних курсів, які складаються із взаємопов'язаних предметних курсів 3 різних дисциплін, які ведуть до професійної компетентності випускників спеціальності. У навчальних курсах з педагогіки та психології вивчаються педагогічні і психологічні навчальні дисципліни, спеціальна педагогіка та різні форми педагогічної практики. Навчальні дисципліни початкової школи, де вивчаються основи окремих предметів, які $є$ у молодших класах початкової школи (чеська мова, література, математика, природничі науки, вітчизняна історія, музики, мистецтво або фізичне виховання і т.д.) Дидактика - вивчається дидактика навчання індивідуальних та вікових особливостей дітей молодшого шкільного віку. Цей процес навчальних дисциплін вводить студентів до теорії та практики викладання окремих предметів початкової школи. Спеціалізація - систематичне вивчення обраної спеціалізації, фокусуючись на будь-якому 3 предметів (музика, художнє мистецтво, драма або фізичне виховання) або на викладанні іноземних мов (англійська, німецька або французька мови). Курси поглиблення - необов'язкові курси для профілізації з окремих предметів [8].

Отже, провідне місце у професійній підготовці вчителя початкової освіти надається педагогікопсихологічні дисциплінам та дидактиці. Протягом навчання студент проходить різні форми педагогічної практики. Так, з другого року навчання студент має можливість пройти педагогічну практику в університетських школах під наглядом вчителів початкової школи і викладачів методики окремих навчальних дисциплін або викладачів 3 дидактики [8]. 


\section{ПРОФЕСІЙНА ПІДГОТОВКА МАЙБУТНІХ УЧИТЕЛІВ ПОЧАТКОВОЇ ОСВІТИ В УНІВЕРСИТЕТАХ ЧЕСЬКОЇ РЕСПУБЛІКИ}

Цікавим педагогічним досвідом, на нашу думку, $\epsilon$ комбінована форма навчання. Комбінована форма навчання набуває форми денного та дистанційного (заочного) навчання. Денне навчання організоване в блоках (лекціях і семінарах), а також у групових та індивідуальних консультаціях. Заочна форма є організаційною формою контрольованого незалежного навчання. Управління процесом навчання здійснюється через електронну пошту, Інтернет (навчальні курси, вимоги, завдання, тексти лекцій, навчально-методичні матеріали, нормативноправові документи в галузі освіти розміщеними на веб-сайті відповідної кафедри) та наданих викладачами навчальних матеріалів. Перевірка такої форми самостійного навчання, здійснюється викладачами за допомогою перевірки навчальних завдань - есе, щоденник студента, порт фоліо вчителя [8].

У Карловому Університеті м. Прага можна навчатися для отримання професійної кваліфікації вчителя 1-го ступеня початкової школи за акредитованої програми "Навчання впродовж всього життя". Студентам пропонують такі можливі варіанти навчання за комбінованою програмою навчання: на початку зимового та літнього семестрів студент обирає форму навчання, зазвичай щотижневе, як правило у вибраний ними день тижня [8].

Проаналізувавши структуру навчальних модулів за напрямом підготовки вчитель 1 ступеню початкової школи в провідних університетах Чеської Республіки ми узагальнили, що всі навчальні програми мають таку структуру:

- 1 - 2 курс навчання в університеті: модуль академічного навчального плану університету історія, філософія, інформаційно-комунікативні технології; тематичний модуль - всі предмети початкової шкільної програми; модуль за додатковою спеціалізацією - мистецтво, фізкультура, музика, англійська, французька та німецька мови; педагогіко-психологічний модуль - основи педагогіки, історія педагогіки, дидактика, основи психології, психологія розвитку; практичний модуль (педагогічна практика) - на 1 курсі - 1 тиждень спостережень за процесом навчання у різних навчальних закладах; на 2 курсі - 1 день на тиждень педагогічної практики - допомога вчителю класу.

- 3 - 4 курс навчання: модуль академічного навчального плану університету - інформаційнокомунікативні технології, соціологія, факультативні курси; модуль за додатковою спеціалізацією - іноземні мови та “навчальні" предмети та їх методика викладання; педагогікопсихологічний модуль - спеціальна педагогіка, методологія педагогіки, факультативні курси; модуль предметного викладання - дидактика всіх предметів відповідно програм навчання в початковій школі; практичний модуль (педагогічна практика) - у дні педагогічної практики в формі допомоги вчителю у рамках методики викладання конкретного навчального предмету початкової школи, 3 обов'язковим визначенням результатів навчання учнів.

- 5 курс навчання: модуль за додатковою спеціалізацією - методики навчальних дисциплін за спеціалізацією; педагогіко-психологічний модуль - факультативні курси; практичний модуль (педагогічна практика) 2-тижнева неперервна педагогічна практика (протягом зимового семестру), 4 тижні неперервної педагогічної практики (протягом літнього семестру) [12, 1113].

Зазначимо, що 5 курс навчання завершується захистом дипломної роботи та державними екзаменами з педагогіки та психології, математики та іiі методики, чеської мови і літератури та їх методики, екзаменом відповідно спеціалізації. Цікавим досвідом, на нашу думку, є те, що під час оцінювання державного екзамену враховується, якість навчальної роботи студентів протягом їх педагогічної практики [1].

Висновки. Аналіз діяльності університетів Чеської Республіки показав, що теоретична i практична підготовка майбутніх учителів початкової освіти здійснюється 3 урахуванням сучасних освітніх вимог, щодо якості надання освітніх послуг. На основі аналізу практики професійної підготовки вчителя початкової освіти в університетах Чеської Республіці можна сформулювати рекомендації щодо модернізації національної системи професійної підготовки майбутніх вчителів початкової школи: законодавчо визначити вимогу, що вчитель початкової освіти повинен здобути ступінь вищої освіти “магістр"; запровадити зміни у процесі професійної підготовки майбутніх вчителів (лекційну форму навчання замінити активними формами навчання); у професійну підготовку майбутніх вчителів доцільно ввести комбіновану форму навчання.

Ці рекомендації сприятимуть розвитку та вдосконаленню системи педагогічної освіти в Україні. Перспективи подальших розвідок убачаємо у розробці шляхів запровадження досвіду професійної підготовки майбутніх учителів початкової освіти Чеської Республіки у систему професійної підготовки майбутніх учителів спеціальності “Початкова освіта" в Україні. 


\section{ПРОФЕСІЙНА ПІДГОТОВКА МАЙБУТНІХ УЧИТЕЛІВ ПОЧАТКОВОЇ ОСВІТИ В УНІВЕРСИТЕТАХ ЧЕСЬКОЇ РЕСПУБЛІКИ}

\section{REFERENCES}

1. Arnon, S. \& Reichel, N. (2007). Who is the ideal teacher? Am I?. Teachers and Teaching: Theory and practice. 13(5), pp. 441-464. [in English].

2. ATEE (2006). The quality of teachers. Recommendations on the development of indicators to identify teacher quality. Brussels, ATEE. Retrieved from: http://www.pef.uni-lj.si/atee/978-961-6637-060/a1-8.pdf. [in English].

3. Bílá kniha - národní program rozvoje vzdělávání v České republice [White Paper -The National Program for the Development of Education in the Czech Republic]. Retrieved from: http:// www.msmt.cz/dokumenty/bila-kniha-narodniprogram-rozvoje-vzdelavani-v-ceske-republiceformuje-vladni-strategii-v-oblasti-vzdelavani-strategieodrazi-celospolecenske-zajmy-a-dava-konkretnipodnety-k-praci-skol. [in Czech].

4. European Commission/EACEA/Eurydice (2015). The Teaching Profession in Europe: Practices, Perceptions, and Policies. Eurydice Report. Luxembourg: Publications Office of the European. Union. Print. [in English].

5. Podlahová, L. (2004.) První kroky učitele. Edice Prvni pomoc pro učitele [First Steps of the Teacher. First Aid for the Teachers]. Praha: Triton, 223 s. [in Czech].

6. Studijní obory Univerzita Hradec Králové [Fields of study University of Hradec Kralove]. Retrieved from: https:/www.uhk.cz/cs-CZ/UHK/ Studium/Studijni-obory.aspx. [in Czech].

7. Učitelství pro 1. st. ZŠ [Teacher of the First School Level.]. Retrieved from: http:// www.vysokeskoly.cz/v/ucitelstvi-a-sport/ucitelstvipro-1-st-zs/. [in Czech].

8. Učitelství pro 1. stupeň (Mgr.). [Teacher of the First School Level (Master)]. Retrieved from: http:// kppg.pedf.cuni.cz/studium/uitelstv-pro-1-stupe-mgr/ charakteristika. [in Czech].

9. Učitelství pro 1. stupeň základních škol (7503T047)[Teacher of the First School Level of Elementary School]. Retrieved from: http:// www.vysokeskoly.com/obor/51001.[in Czech].

10. Vašutova, J. (2004). Profese učitele v českem vzdělavacim kontextu [Profession of a Teacher in Czech Educational Content]. Brno: Paido. 190 s. [in Czech].

11. Vašutová, J.; Spilková, V. (2011). Teacher Education in Czech Republic. In Valentič Zuljan M.; Vogrinc, J. (eds). European Dimensions of Teacher Education-Similarities and Differences. Ljubljana.: Faculty of Eduaction, University of Ljubljana, ss. 193224. [in Czech].

12. Wildova R. (2014) Training Primary School Teachers - Issues and Trends Republic. Procedia Social and Behavioral Sciences. 141. đđ.1112-1115. [in English].

13. Zákon č. 561/2004 Sb. Zákon o předškolním, základním, středním, vyšším odborném a jiném vzdělávání (školský zákon) [Education Act. Law on Pre-School, Primary, Secondary, Higher Professional and Further Education (School Law)]. Retrieved from: https://www.zakonyprolidi.cz/cs/2004-561. [in Czech].

14. Zakon o pedagogickych pracovnicich 563/2004 $\mathrm{Sb}$ [Law on Pedagogical Workers]. Retrieved from: http://www.msmt.cz/dokumenty-3/zakon-opedagogickych-pracovnicich-1. [in Czech].

Стаття надійшла до редакції 15.03.2018

\section{G5}

“Жобобійти до мети, потрібно, пери за все, йти".

$$
\begin{array}{r}
\text { Оноре де Бальзак } \\
\text { франиузъцй романіст і драматург }
\end{array}
$$

“Кожна людина повинна переважно братися за те, що для неї можливо і що для неї пристойно".

Apicmoтель

давньогрецький вчений-енщиклопедист

"Же будуйте дрібних планів - в них немає тієї чарівної сили, яқа розбурхує қров, $i$, иммовірно, не будуть реалізовані. Будуйте грандіозні плани, ставте висоқі иілі у своїх надіях $і$ в роботі, пам'ятаючи про те, що грандіозний, логічно складений план ніколи не зникне".

Dжеймс Бернхем

американский ббілособ, соиіолог

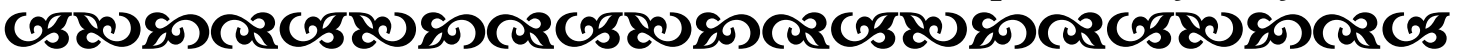

Молодь і ринок №4 (159), 2018 